\title{
World War I and Internal Repression: The Case of Major General Nikolaus Cena*
}

\author{
IRINA MARIN
}

$\mathrm{O}$

N 24 August 1914, Lieutenant General Artur von Bolfras warned his peer Franz Conrad von Hötzendorf that the draconian measures directed against domestic suspects were causing a lot of trouble and amounted to throwing the baby out with the bath water by fostering internal animosity. "We should not," Bolfras insisted, "unnecessarily antagonize the population who have so far shown themselves to be loyal and ready for sacrifice beyond all expectations." He urged in particular that Conrad should use his influence to put a stop to the excesses of the military command in Temesvár in southern Hungary, where, starting in late July 1914, hundreds of arrests were made following the partial mobilization against Serbia, thus putting into practice Conrad's professed military rationale: "better lock up one hundred people than one too few."' The initial spate of arrests and internments that accompanied the mobilization for war continued well into the autumn of 1914, snowballing into virulent state-driven repression, targeting mostly, but not only, Serbs, a situation which Josef Redlich referred to in his journal as a "race war" and a "systematic policy of extermination." 2 To Bolfras's letter of notification, Conrad replied that orders had been wired to Temesvár to the effect that abuses should be avoided and the

\footnotetext{
${ }^{\star}$ I would like to thank Professor Pieter Judson for his support and encouragement with the publication of the present article, as well as the $A H Y$ anonymous referees for their constructive comments and their valuable suggestions and criticisms. I am also indebted to a number of people for their generous help and support in researching and improving this article: the archivists of the Kriegsarchiv in Vienna and, in particular, Dr. Michael Hochedlinger; Dr. Antonio Schmidt-Brentano; Professor Lothar Höbelt; Mr. Trevor Thomas; Dr. Tamara Scheer; Professor Dennis Deletant; Dr. Tom Lorman; Professor Martyn Rady; Professor Robert Evans; Dr. Zoran Milutinović, Colonel Liviu Groza; and Dr. Daniel Brett. As a version of the present article was given as a paper at the 2011 conference Cultures at War: Austria-Hungary 1914-1918 (St Hilda's College, University of Oxford), I would also like thank the organizers and participants for their feedback and useful comments. Thanks are also due to the Rațiu Family Foundation in the UK, which sponsored my doctoral research.

${ }^{1}$ Conrad von Hötzendorf, Aus meiner Dienstzeit, 1906-1918, vol. 4 (Vienna, 1921-1925), 135 and 549-50: “ besser hundert Leute einsperren als einen zu wenig."

${ }^{2}$ Das politische Tagebuch Josef Redlichs, I. Band (1908-1914) (Graz/Cologne, 1953), 280; Mark Mazower, The Balkans: From the End of Byzantium to the Present Day (London, 2003), 118-19.
} 
military should work harmoniously with the civilian authorities, but he also signified that "we here can't do anything about individual abuses."3

The situation was not substantially different in the other half of the monarchy, where preparations for war occasioned a similar spate of arrests that overshadowed the enthusiasm of the Augusterlebnis, as the initial war euphoria came to be known. As documented by Martin Moll, 800 arrests alone took place in Styria, a region which in 1914 was not close to any of the front lines. For a long time, this wave of internal repression was attributed exclusively to the military. Building on Christopher Führ's work, Moll uses the Styrian example as evidence that the relationship between military and civilian authorities shortly before and during World War I did not subordinate the latter to the former; it by no means amounted to a "dictatorship of the army high command." Moll argues that it was not so much the central military authorities that were to blame for arbitrary arrests and overzealousness as it was the local gendarmerie. ${ }^{4}$

Although internal repression soured relations between the population and the local government in both halves of the monarchy, there were considerable differences between the two in terms of the distribution of powers and the institutions wielding these powers. In Cisleithania, the Parliament and the Crownland diets were discontinued, and the War Surveillance Office (Kriegsüberwachungsamt), whose existence preceded the outbreak of war, came into its own for the duration of the hostilities. By contrast in Hungary, Parliament continued to convene throughout the war and there was no counterpart to the War Surveillance Office. Such an institution was rejected as an infringement of Hungarian autonomy and an intolerable interference of Vienna into Hungarian internal affairs. There was also no need for it, since the Hungarian state apparatus had its own effective secret policing system. ${ }^{5}$ The most important distinction between the two halves of the monarchy at the beginning of the war, however, was the set of laws that regulated relations among the government, the army, and the population in case of war or impending warthe Ausnahmezustandgesetz for Cisleithania and the Emergency Law for Hungary. In the Austrian half of the monarchy, the law "strengthened the state apparatus" as a whole, enhancing in equal measure the powers of the military and of the civilian administration; ${ }^{6}$ whereas in Hungary, the Emergency Law was formulated so as to preclude any military inroads into civilian jurisdiction. Instead it concentrated all exceptional powers deriving from the state of emergency into the hands of the Hungarian government, so that the military command had to work in agreement with the Hungarian authorities. This, as Galántai points out, led to "friction and quarrels between the Hungarian government and the high command of the common army stationed in Hungary."7

This article contributes a case study to the literature on World War I internal repression in Austria-Hungary: the case of retired Major General Nikolaus Cena arrested in July 1914 by the Hungarian authorities and held in prison for a month before being finally released and sent to Vienna. I have stopped at this particular instance of arrest for several reasons. First, given the

\footnotetext{
${ }^{3}$ Conrad von Hötzendorf, Aus meiner Dienstzeit, vol. 4, 551: “für die Übergriffe Einzelner können wir hier nichts.”

${ }^{4}$ Martin Moll, "Erster Weltkrieg und Ausnahmezustand, Zivilwaltung, und Armee: Eine Fallstudie zum innerstaatlichen Machtkampf im steirischen Kontext," in Focus Austria: Vom Vielvölkerreich zum EU-Staat, Festschrift für Alfred Ableitinger zum 65. Geburtstag, ed. Siegfried Beer, 383-407 (Graz, 2003).

${ }^{5}$ Tamara Scheer, "Das k. (u.) k. Kriegsüberwachungsamt und die Zensur Frage. Ein Beitrag zur Sicherung der Heimatfront," Journal for Intelligence, Propaganda and Security Studies 1, no. 2 (2007): 70-82.

${ }^{6}$ Moll, "Erster Weltkrieg und Ausnahmezustand, Zivilwaltung, und Armee: Eine Fallstudie zum innerstaatlichen Machtkampf im steirischen Kontext," 387.

${ }^{7}$ József Galántai, Hungary in the First World War (Budapest, 1989), 77.
} 
lack of a synoptic study of start-of-the-war repression across the two halves of the monarchy and the lack of sufficient information on all the regions of the empire regarding this initial spate of arrests to warrant generalization and comparison, the Cena case contributes new data on the situation in southern Hungary along the border with Serbia and Romania. Second, as we shall see in what follows, when compared with studies such as Moll's on the Slovenes in Styria, the Cena case evinces striking similarities at the level of governmental and military reactions and justifications. It also contributes to the argument that the military was not primarily as responsible for domestic repression at the beginning of the war as were local civilian authorities. Third, what is specific about this case is the status of the protagonist, a retired imperial high-ranking officer, whose arrest demanded explanations from the highest places in the Austro-Hungarian hierarchy (as shown by the correspondence between War Minister Krobatin, Hungarian PM Tisza, and Justice Minister Balogh). The case illuminates not only the relationship between the k.u.k. military authorities and the Hungarian civil authorities, but also the play of assumptions, expectations, and reactions of Cena as a highranking imperial officer involved in an espionage investigation that was riddled with irregularities.

\section{Cena's Origins in the Military Border}

Major General Nikolaus Cena (1844-1922) was a native of the Banat segment of the Habsburg Military Border (Militärgrenze), a defense belt of militarized territory dating back to the sixteenth century, initially limited to part of the Croatian lands and conceived as a buffer zone between the Habsburg possessions and the Ottoman Empire. Beginning in the eighteenth century, this territory, stretching from the Adriatic to the Transylvanian border, acquired an organizational structure of its own, as a self-sustaining economic system based on a feudal-type distribution of land in exchange for military service and placed under the control of a centralized military administration. An important item on Empress Maria Theresa's agenda of military reform following the Silesian debacle, the organization of the Military Border institution aimed at "converting an irregular frontier militia into a rigidly disciplined and ever-ready military force, maintained at little or no cost to the state in times of peace." At its high watermark, the Military Border included Croatian, Serbian, German, Romanian, and Székely regiments. ${ }^{9}$ The Banat segment of the Military Border was comprised of a German Regiment, a Serbian Battalion, and a Romanian Regiment. The Border was gradually dissolved as an anachronistic institution in the wake of the 1867 Compromise so that by the 1880s, it was included in the Hungarian half of the monarchy. Still, a strong sense of Grenzer identity lingered on among the population of the former Military Border.

Cena was born in Mehádia, in the territory of the Romanian Banat Border Regiment, and as a descendant of a Grenzer family, he embarked on a military career. His father, Nestor Cena, had been a first lieutenant in the Romanian Banat Border regiment and had fought in Italy during 1848-49. The son, Nikolaus Cena, attended the military school in Karánsebes, then the pioneer school in Tulln, and saw action during the 1866 war against Prussia.

\footnotetext{
${ }^{8}$ Gunther E. Rothenberg, The Military Border in Croatia, 1740-1881: A Study of an Imperial Institution (Chicago/ London, 1966), 22.

${ }^{9}$ The Székelys are a group speaking an archaic dialect of Hungarian whom the Hungarian Crown sent to colonize eastern Transylvania in the medieval period. They acted as border guards and constituted one of the three political nations in the Hungarian Kingdom together with the Hungarian aristocracy and the Saxons.
} 
Cena was not the first general to come from the Banat Military Border. The first Banat Border officer reached the rank of general in 1872. By 1918 the militarized population of the Romanian Banat Border Regiment had given the Austro-Hungarian army fifteen generals. ${ }^{10}$ The relative celerity of promotion was due to both the new meritocratic system of promotion in place in the Habsburg army since the middle of the nineteenth century and to the intensive military training provided in the Military Border, where education was strongly oriented toward military formation and dominated by military schools. As Antoniu Marchescu pointed out, here:

public education was greatly valued under the military regime. Primary school attendance became mandatory as early as 1829 , while in Hungary it was introduced only in 1869 . Military education was the principal goal of the schools. They had, therefore, a pronounced military character. Each commune was entitled to a local school in the native language of its inhabitants. The local national school was followed by the trivial school ${ }^{11}$ in the company headquarters town, with German as the language of tuition. The best three students in the commune went on to attend the trivial school and afterwards the superior school, which trained them to become non-commissioned officers. The mathematical school, located in the regimental headquarters town, prepared officers. ${ }^{12}$

Between the setting up of the Banat Border Regiment in 1768 and the 1850 relaxation of laws on the choice of profession, the only channel of social and economic advancement remained the military career. The occupational constrictions legislated by the 1807 Military Border Constitution resulted in a professional Hobson's choice, which shaped the social dynamics of the Military Border in a decisive way. The almost one hundred years of institutional pressure led to the evolution of military family traditions among the frontiersmen, which becomes apparent in the biographical profiles of later generals as recorded in their lists of characterization (Qualificationslisten). This family tradition, as well as the availability of military schools in the Grenze, acted as an incentive for capable young men to pursue a military career and to rise within the ranks.

Cena's career was characteristic of the new type of promotion system along meritocratic lines. In times of peace (which is what the latter half of the nineteenth century mostly offered), as a valuable military technician and specialized officer, he held several positions as a teacher and commander of various military schools: at the Cadettenschule in Temesvár, Karlstadt, Karthaus (Königsfeld bei Brünn), and Kamenitz. His didactic and organizational activity earned him imperial recognition and decorations, as recorded in his Qualificationsliste. Of lowly extraction and without being eligible for a state-sponsored place in one of the military academies, Cena climbed the military hierarchy by virtue of his intellectual abilities. His promotion to general was facilitated not by graduation from the military academies, but rather by attendance at the Staff officers course [Stabsofficiers-Curs] (a course providing training with a view to promotion to General Staff officer), which functioned as a trampoline to reach higher military echelons. Nikolaus Cena, one of the few Romanian officers who

\footnotetext{
${ }^{10}$ Antoniu Marchescu, Grănicerii bănățeni și Comunitatea de Avere (Contribuțiuni istorice și juridice) [The Banat Frontiersmen and their Commonwealth (Historical and Juridical Contributions)] (Caransebeş, 1941), 295-96; hereafter Grănicerii bănățeni.

${ }^{11}$ According to V. Ţîrcovnicu, outside the Military Border, trivial was another name for national schools, whereas within the Military Border, it designated a distinct and higher level of education. Victor Țîrcovnicu, Contribuții la istoria învățământului românesc din Banat (1780-1918) [Contributions to the History of Romanian Education in the Banat (1780-1918)] (Bucharest, 1970), 44, 72.

${ }^{12}$ Marchescu, Grănicerii bănățeni, 270.
} 
achieved the rank of Major General in the k.u.k. army, started his career by attending the military engineer school (Pionierschule) in Tulln and ascended the military hierarchy by means of further qualifications, in particular the above-mentioned General Staff officer course. ${ }^{13}$ He was received into the ranks of the service nobility upon receiving the Ritterkreuz des Franz-Joseph Ordens in 1896. He retired in 1904 as a Major General, the third highest rank in the Austro-Hungarian army. ${ }^{14}$

Cena was not a singular figure in the context of Romanian officers who originated from the Military Border. As mentioned above, the Romanian Banat Border regiment was the native place of fifteen officers who made it to one of the ranks of general between 1870 and 1918 . The most prominent of these and a local hero among the population of the Banat Military Border was Brigadier General Trajan Doda (1822-1895), who went into politics after his retirement and served as an MP for the Romanian National Party in the Hungarian Parliament where he fought for national rights. Others such as Brigadier General Michael Trapsia, Brigadier General Alexander Lupu, and Major General Theodor Seracin, once retired, took an active part in Romanian cultural activities, supporting literary journals, providing funding for national schools, supporting the Romanian Orthodox Church, etc. The Military Border was the type of environment that did not repress national identity. On the contrary, it specifically harnessed national awareness and imperial loyalty together. ${ }^{15}$ Things were no different in the Croatian segment of the Military Border, where fervid national awareness was only matched by equally fervid loyalty to the Habsburg emperor.

\section{Cena's Arrest and Investigation}

On 26 July 1914, the General Staff Command of Corps 7 in Temesvár, southern Hungary, wired orders to the Orsova Honvéd station on the Danube border with Serbia to proceed to arrest the people placed on their list of suspects. On the same day, the Orsova Honvéd commander summoned the head of the Border Police, the gendarmerie commander, and the Oberstuhlrichter (chief district administrative officer). He announced that, since mobilization had been declared, he was henceforth taking control of all local authorities and handed over to them the list of suspects to be arrested that very night. ${ }^{16}$ When compared to the situation in Styria as described by Moll, a number of similarities become apparent. In the Austrian half of the monarchy, orders came from the k.u.k. Military Command in Graz to the civilian authorities instructing them to indicate all the "publishing or printing houses, journal and gazettes belonging to the Social Democrats or which disseminated anti-military and antidynastic publications." The governor, Manfred Graf Clary-Aldringen, complied with these orders and on his own initiative also ordered the creation of lists of political suspects from among the local population. ${ }^{17}$ In southern Hungary, the lists of suspects were similarly

\footnotetext{
${ }^{13}$ OeStA, KA, Qualificationsliste, Karton Nummer 338 (Cejnek-Cencur).

${ }^{14}$ OeStA, KA, Qualificationslisten, Karton Nr. 338 (Cejnek-Cencur), Nikolaus Cena, National und Dienstbeschreibung für das Jahr 1903, f. 3.

${ }^{15}$ Liviu Groza, Contribuții la cunoaşterea culturii grănicerilor bănățeni [Contributions to the Culture of Banat Frontiersmen] (Lugoj, 1993); Irina Marin, "The Formation and Allegiance of the Romanian Military Elite Originating from the Banat Military Border" (PhD diss., University College London, UK, 2009).

${ }^{16}$ OeStA, KA, KM Präs, 1914, Karton 1583 (40/1-41/3), Aktenzahl 40-19/5, Referat, der Vorstand der 4. Abt. im k. u.k. Kriegsministerium, Wien am 14. Oktober 1914, f. 19r: "daß er infolge der Mobilisierung die Verfügung über alle Behörden übernehme."

${ }^{17}$ Moll, 389-90.
} 
drawn up by the local civilian authorities, the only difference being that in Hungary these lists of suspects were already in place and were simply acted on when orders arrived from the k.u.k. military authorities in Temesvár. The major difference between the two regions was that whereas Styria was far removed from the front, southern Hungary was very close to the Serbian border. As the Cena case will show, in Hungary the state of mobilization brought into effect the Hungarian Emergency Law, which gave extensive powers to the Hungarian government and state apparatus, who did their own thing without informing the k.u.k. military command of their procedures.

Since retired General Nikolaus Cena figured among the suspects on the Orsova Border Police list, he was duly arrested and transported, together with the other detainees, to the Karánsebes Tribunal Prison. Mention of this arrest is made in a study dedicated to Cena and published in 1924 by Coriolan Buracu, the local Orthodox priest of Mehádia and a close friend of Cena's, himself arrested during the same night. His account of Cena's arrest is based on the general's autobiography, out of which Buracu quotes the following passage:

At 10 am two ordinary gendarmes came to my house and declared I was being arrested. Thinking I did not hear well, I asked them what they wanted. A sergeant replied, "You are under arrest, come with me." I was astonished: I was being arrested by two ordinary gendarmes, instead of officers as required by regulations. I asked to see the order of arrest. They showed it to me. There was nothing else for me to do than to obey. I told them to wait until I changed my general's uniform and put on civilian clothes. While I was changing, I dictated to my nephew, who happened to be there, telegrams to Corps 7 in Temesvár, to the War Ministry in Vienna, and to the Honvéd Ministry in Budapest, asking for intervention. These telegrams never reached their destination. ${ }^{18}$

The arrests of 26 July 1914 occurred two days before Austria-Hungary declared war on Serbia, during the partial mobilization that followed Serbia's rejection of the Austro-Hungarian ultimatum. ${ }^{19}$ As the Hungarian Minister of Justice Balogh pointed out in a report to Krobatin, the Austro-Hungarian war minister, numerous people considered political suspects and placed under surveillance were arrested during this phase of mobilization and as many as eight hundred were prosecuted. ${ }^{20}$ By September 1914, almost two months after the partial mobilization in Orsova, during which Cena and others were arrested, requests for intercession were still circulating on behalf of some of the detainees. ${ }^{21}$ Thus, Cena's detention was not an isolated, exceptional case, but rather part of an overzealous rush to prosecution that lumped together citizens of various categories (as can be seen from the occupation column in the list of suspects of the Border Police in Orsova ${ }^{22}$ ) and various nationalities (Bulgarians, Hungarians, Jews, Romanians, Serbs, Turks). ${ }^{23}$ What set apart Cena's case was his prominent position as a retired and several times decorated major general (which, as correspondence shows, entitled him to being addressed "Your

\footnotetext{
${ }^{18}$ Ibid., 5.

${ }^{19}$ József Galántai, Die Österreichisch-Ungarische Monarchie und der Weltkrieg (Budapest, 1979), 345.

${ }^{20}$ OeStA, KA, KM Präs 1914, Aktenzahl 40-19/5, f. 6r.

${ }^{21}$ See the letters in the Valeriu Branişte archive concerning the arrests made at the beginning of the war in the Banat: ANCN, Fond Personal Valeriu Branişte, Pachet VI, Nr. act. 213, 10 September 1914 letter from G. Noaghea to Valeriu Branişte; and Pachet VI, Nr. act. 152, 14 November 1914 letter from Nicolae Ionescu to Valeriu Branişte.

${ }^{22}$ OeStA, KA, KM Präs 1914, Aktenzahl 40-19/5-3, ff. 38-39.

${ }^{23}$ ANCN, Fond Personal Valeriu Branişte, Pachet VI, Nr. act. 152, 14 November 1914 letter from Nicolae Ionescu to Valeriu Branişte, f. $2 \mathrm{v}$.
} 
Excellence"), as well as his advanced age (at seventy he was the oldest detainee on the Orsova Border Police list of suspects).

On 3 August 1914, the public prosecutor in Karánsebes contacted the Honvéd Command in Orsova, inquired into the grounds for Cena's arrest, and proceeded to launch an investigation on 9 August. $^{24}$ This differed from similar cases in Styria, where the accused were brought before military tribunals. It also differed from arrests in other parts of Hungary. For instance, the Slovak leader Milan Hodža, arrested on 30 July 1914, was brought before a military tribunal (Divisionsgericht) and, because the accusations against him were so tenuous, was curtly dismissed by the military judge with the line "I have no time for such silly things!" 25 By contrast, in Cena's case, the month-long investigation seems to have been conducted by civilian authorities only. Cena was finally released on 24 August, while the investigation was formally closed on 10 September. Why was Cena arrested in the first place? Why did the War Ministry in Vienna fail to react in any way to the arrest of a major general? Why was Cena released at the end of August even though the investigation dragged on until early September? On whose authority was he eventually set free? The answers to these questions are to be found in the extant documents of the Cena case in the War Surveillance Office archive in Vienna.

The earliest notification of Cena's arrest is one of the telegrams the general dictated to his nephew on 26 July, which, contrary to what Cena himself thought, did reach the War Ministry in Vienna and was registered by the War Surveillance Office on 30 July. $^{26}$ This is the image the k.u.k. military authorities had of the sender, as becomes apparent in the short description scribbled on the back of the telegram: "Cena Nikolai EKO-R3, FJO-R, MKV / Retired Major General, permanent address Mehadia; / Short man in pince-nez, corpulent, speaks fast, keeps himself to himself (verschleiert), / German-Croatian." 27 And this is what they thought had happened to him, as the penciled note appended to the telegram shows:

Retired Major General Cena / Message from the representative of the Hungarian Ministry of the Interior / On 25/7 at night the retired Major General Cena was arrested by the local Gendarmerie Command on the order of the Stationskommando in Ujvidék being suspected of espionage. On 27 July he was allowed to return to his native place on the promise that he would remain there. ${ }^{28}$

These and the following documents in the War Surveillance Office archive relative to the Cena case are evidence of a certain communications breakdown between Vienna and Budapest. Thus, on 15 August 1914, a telegram from Ottokar Graf Czernin, the Austro-Hungarian ambassador in Bucharest, drew attention to the harmful effects of local press allegations that General Cena had been imprisoned or even shot and urged the government to make an official denial of these rumors. One of the notes scribbled at the bottom of Czernin's deciphered telegram points out

\footnotetext{
${ }^{24}$ OeStA, KA, KM Präs, 1914, Karton 1583 (40/1-41/3), Aktenzahl 40-19/5-2, Vorstand der 4. Abt. im k.u.k. Kriegsministerium, REFERAT zu Präs. Nr. 13966 von 1914 betreffend den FMLt. d.R. Nikolaus CENA, 19.

${ }^{25}$ Das politische Tagebuch Josef Redlichs, I. Band (1908-1914), 66: "für solche Dummheiten habe ich keine Zeit!"

${ }^{26}$ OeStA, KA, Kriegsüberwachungsamt (henceforth KÜA) 1914, Aktenzahl 107, 1st item, recto.

${ }^{27}$ OeStA, KA, KÜA 1914, Aktenzahl 107, 1st item, verso: "Cena Nikolai EKO-R3, FJO-R, MKV / Tit.-Charge Pens. Fmlt., ständ. Aufenth. Mehadia / Kl. Mann im Zwicker, corpulent, rasch sprechend, verschleiert, deutsch-kroatisch.”

${ }^{28}$ OeStA, KA, KÜA 1914, Aktenzahl 107, 2nd item, recto: "FMLt d. R. Cena / Mitteilg des Vertreters des ung. Min. d. Inn. / Am 25/7 nachts wurde FMLt d.R. Nikolaus Cena über Befehl des Stationskmdos in Ujvidék als der Spionage verdächtig, durch das dortige Gendarmerie-Flügel Kdo verhaftet. Am 27 Juli wurde er über ehrenwörtliche Verpflichtung, in seine Gemeinde abzureisen und sich dort aufzuhalten freigelassen.”
} 
that the Ministry of Foreign Affairs had been informed that General Cena was free (sich auf freiem Fuß befindet), although they were not apprised of his current whereabouts. ${ }^{29}$

A document dated 29 August 1914 and addressed to the Hungarian prime minister shows that the War Ministry in Vienna had not known anything about Cena's one-month arrest before Cena was released and he himself informed the Ministry upon his arrival in Vienna. In the same document, the Viennese War Ministry (the act bears the signature of War Minister Krobatin, among others) asked for explanations and expressed their surprise at the treatment received by Major General Cena while under arrest, as well as at the fact that the detention had taken place without the knowledge of the War Ministry and, as it appeared to them, without that of Count Tisza. In addition, they were surprised that the release had been made in the name of the War Ministry. ${ }^{30}$

The said document was based upon a declaration given on the same day by Major General Cena to the War Surveillance Office, in which he recounted that on 24 August, after almost onemonth in prison, the state prosecutor spoke to him as if on behalf of the War Ministry and made him a proposal of release, which was conditional on his agreeing to leave the country within three days. ${ }^{31}$ It was the clash between Cena's declaration and the information the War Ministry had received up until then that set the bureaucratic machine in motion and resulted in several detailed reports from the state prosecutor in Karánsebes, from Tisza, and from the Hungarian minister of justice. All of these essentially bear out Cena's testimony and also flesh out the body of accusations brought against him, which eventually proved too tenuous to lead to condemnation.

There were three main grounds of suspicion against Cena as communicated by the state prosecutor in Karánsebes. ${ }^{32}$ First, he was placed under suspicion for taking numerous photographs of Mehádia and its surroundings, in particular of railways, bridges, tunnels, and ruins, some of which subsequently ended up in the hands of a certain Romanian officer by the name of Jon Rosu and of others suspected of espionage. Second, he had old maps of Mehádia copied from the archive of the District Tribunal ( $k$. Bezirksgericht $)$ in Orsova. Third, earlier that summer, he had received a visit from two generals from Romania. Cena defended himself against the first two accusations by maintaining that he was gathering material for a history of his native village Mehádia and intended to use the photographs and maps for illustration purposes. As to the visit of the two Romanian generals, by his own admission, this had taken place on 12 July that year, and he presented it as nothing more than a courtesy call. Of the two generals, Mujka and Musztecza, Cena had met the former in 1911 in Romania when Mujka was still a colonel; the latter was a new acquaintance. The state prosecutor's report records part of the dialogue between General Musztecza and Cena, as recounted by Cena: “During the conversation he strongly rejected General Musztecza's assertion that the Romanian army was better than the Austro-Hungarian; when General Musztecza said 'Things could turn out in such a way that Romania might find itself involved in a war against Austria-Hungary,' Cena replied, 'I would be very sorry about that, but you would find us on the other side." 33

\footnotetext{
${ }^{29}$ OeStA, KA, KÜA 1914, Aktenzahl 1597, f. 1r.

${ }^{30}$ OeStA, KA, KÜA 1914, Karton 5, Aktenzahl 2922, Folios 1-2.

${ }^{31}$ OeStA, KA, KM Präs, 1914, Aktenzahl 40-19/5, f. 4v.

${ }^{32}$ OeStA, KA, KM Präs, 1914, Karton 1583 (40/1-41/3), Aktenzahl 40-19/5, ff. 23-24.

${ }^{33}$ OeStA, KA, KM Präs, 1914, Karton 1583 (40/1-41/3), Aktenzahl 40-19/5, ff. 23v-24r: "Während des Gespräches wies er die Behauptung des Generals Musztecza, dass die rumänische Armee besser ist wie die öst.ung mit heftigen Widerspruch zurück, als dieser General Musztecza sagte 'es können sich die Verhältnisse so gestalten, dass
} 
While one is inevitably wary of such a reported conversation, given that Cena communicated it to the prosecutor in an attempt to defend himself against accusations of espionage, nevertheless, it shows that he did have contacts among high-ranking Romanian officers and that the subject of the Romanian army and of side-taking during a possible war did come up during this courtesy visit.

One of the Hungarian reports on the Cena case available in the Viennese War Archives presents the stages of the investigation and focuses on the interrogation of Cena. The report conveys the scope of Cena's activities and the manner in which he became acquainted with Romanian fellow officers. In his official statement to the Karánsebes tribunal, Cena mentions his contribution to the 1911 issue of the yearbook published by the Viennese Academy of Sciences, as well as his intended book titled Bilder aus der Vergangenheit und Gegenwart der Grossgemeinde Mehadia. The wealth of maps found in his house is explained by his profession (Cena had been a military engineer) and also by his position as president of the Orthodox parish committee and his involvement in the management and administration of Mehádia. Cena also relates how he met the then Colonel Mujka when attending a military parade in Romania. ${ }^{34}$

Cena's contacts with the Romanian military were by no means something out of the ordinary for a k.u.k. officer. Since its foundation in the 1850s, the Romanian army received many Romanian recruits from the Habsburg lands, and two of its prominent generals (Moise Groza and Ioan Dragalina) came from the Banat Military Border, having been officers in the Austro-Hungarian army who subsequently emigrated to Romania. Moreover, Romanian officers regularly attended Austro-Hungarian military maneuvers, and King Carol I of Romania himself was an officer in the k.u.k. army.

\section{Cena's Release and Demand for Satisfaction}

Cena was not set free thanks to an intervention on the part of the military authorities, although much was made of his major general status after his release. As pointed out above, the War Ministry in Vienna had not known about Cena's one-month imprisonment until Cena himself apprised them of it. Although his arrest was ordered by the military, the investigation was conducted by civilian authorities, namely the Karánsebes state prosecutor. Cena's release also came about as a result of civilian intervention, and this from the highest level. The royal state prosecutor (k.u. Staatsanwalt) in Karánsebes confirmed in his report that he had set Cena free following orders received by telephone from the head state prosecutor ( $k$. Oberstaatsanwaltschaft) in Temesvár, ${ }^{35}$ who in turn had his orders from Prime Minister Tisza himself. As Tisza explained in his report to War Minister Krobatin:

At the end of the investigation, the Head State Prosecutor in Temesvár asked on the 22 August the Command of Corps 7 to what extent [Cena's] photographs of bridges, given that they were for the

Rumänien mit Österreich-Ungarn in einen Krieg verwickelt wird,' drauf hat er erwidert 'Es würde mir sehr leid thun, aber da werdet Ihr uns gegenüber finden."”

${ }^{34}$ OeStA, KA, KM Präs, 1914, Karton 1583 (40/1-41/3), Aktenzahl 40-19/5, Confidential report A cs. és kir. 7. hadtest Vezérkari Osztályának, from Dr. Gozsdu Elek, Royal Chief Prosecutor with the Royal Tribunal in Temesvár, dated 22 August 1914, f. 11r: "1911 évben a Romániában a király tiszteletére rendezett katonai ünnepségre elment s ott magas rangú tisztekkel—köztük egy Mujka nevű román kir. Ezredessel—is megismerkedett.”

${ }^{35}$ OeStA, KA, KM Präs, 1914, Karton 1583 (40/1-41/3), Aktenzahl 40-19/5, K. Staatsanwaltschaft in Karánsebes, Beschluss, f. 23r. 
most part taken from under the bridges, could be considered incriminating evidence. Before, however, an answer to this inquiry could arrive, Major General Cena was released on the 24 August due to my intercession under the condition that he go to Austria for the duration of the war. ${ }^{36}$

Tisza was no bosom friend of the Romanians. As the Austrian journalist Friedrich Funder remembered in his memoirs, Tisza once remarked to him, "Dr. Funder, you support the Romanians and I'm telling you, they are a courageous people, but every Romanian that wears long trousers is a traitor to his country (ein Landesverräter)." ${ }^{\prime 37}$ The long trousers were those worn by the middle classes as opposed to the long stockings of the peasantry. Funder had occasion to see how Tisza acted on his opinion and also to confirm the extent of his influence. In a discussion with Iuliu Maniu, a young lieutenant and leader of the Transylvanian Romanians, who was stationed in Vienna at the end of the war, Funder was told how Maniu was drafted into the army in 1916, although he was exempt, and how in 1918 he had the chance to see his military record, or Conduitenliste, at the War Ministry. He found appended to his military record a telegram from Tisza to the War Ministry dated March 1916 in which Tisza expressed his wish that Maniu should report for duty at once and thus be given the possibility to prove his patriotism at the front. ${ }^{38}$ Apart from this memorable incident, Tisza was convinced even before the war started of the unreliability of Romanians both in Hungary and in Romania, as shown by his initial objections to a war against Serbia for fear that Romania would attack Hungary and try to take Transylvania. ${ }^{39}$

This being Tisza's attitude toward Romanians in general, it is highly unlikely that his intercession on Cena's behalf was done as a personal favor to the retired general. From the rest of the report, it becomes apparent that the Cena case was an opportunity for Tisza to reiterate his objection against Austrian military interference in Hungarian affairs. Tisza thus used this case to reproach Vienna with "this whole system of espionage and secret policing." ${ }^{\prime 0}$ This reproach comes across as rather odd, given that Cena was detained and investigated by Hungarian civilian authorities and only makes sense if viewed in the wider context of the tug of war, which József Galántai mentioned, between Austrian military authorities and Hungary's civilian government. Tisza was to send a note of warning to the Military Chancery in September 1914, in which he warned that arrests should be made only on the basis of strong evidence; otherwise, they ran the risk of making enemies out of loyal citizens. ${ }^{41}$ Tisza's phrasing is almost identical with Clary's warning against abusive arrests in Styria, which only "create bitterness and animosity among correct and patriotically minded

\footnotetext{
${ }^{36}$ Tisza's letter to Krobatin, OeStA, KA, KM Präs, 1914, Karton 1583 (40/1-41/3), Aktenzahl 40-19/5, BUDAPEST, 4 September 1914 , f. 3 r.

${ }^{37}$ Funder, Vom Gestern ins Heute. Aus dem Kaiserreich in die Republik (Vienna, 1952), 542.

${ }^{38}$ Ibid., 535-36.

${ }^{39}$ József Galántai, Hungary in the First World War, 28-30.

${ }^{40}$ OeStA, KA, KM Präs, 1914, Karton 1583 (40/1-41/3), Aktenzahl 40-19/5, f. 3v: "dieses ganze System von Espionage und Geheimpolizistentums.”

${ }^{41}$ Christoph Führ, Das k.u.k. Armeeoberkommando und die Innenpolitik in Österreich (1914-1917) (Graz/Vienna/ Cologne, 1968), 28: "Es sind vielfache Klagen eingelaufen, daß in letzterer Zeit neuerlich zahlreiche Verhaftungen von angeblich politisch Verdächtigen oder Unzuverläßlichen in allen Teilen der Monarchie stattgefunden haben, Verhaftungen, welche fast lediglich auf Veranlassung oder über Anforderung militärischer Kommandos und Behörden erfolgen. Ich befehle, daß alle militärischen Stellen strengstens angewiesen werden, derartige Maßnahmen nur auf Grund schwerwiegender Verdachtsmomente zu veranlassen. Ich will nicht, daß durch unberechtigte Verhaftungen auch loyale Elemente in eine staatsschädliche Richtung getrieben werden."
} 
population." 42 The Cena arrest thus came in handy for Tisza as an argument against the military authorities keeping a tight grasp on the Hungarian border with Serbia. Mehádia, Cena's place of residence, was located in southern Hungary, more precisely in southeastern Banat, at the very point where the two borders, with Serbia and Romania, intersected.

Although the investigation of Cena resulted in no actual trial and was discontinued in early September 1914 for lack of hard evidence, Cena asked the military authorities for satisfaction for what he considered to have been ignominious treatment received during his one-month arrest. The retired general also insisted on being vindicated before his peers by a military Ehrenrat, ${ }^{43}$ a council of honor, before which he could refute the accusations and clear his name of the moral blemish that he had incurred by association with espionage charges. In his plea to the War Ministry, Cena reiterated his loyal service to emperor and fatherland and his wish to end his life as an honorable man, free of the shadow of ignominy. ${ }^{44}$

This insistence on having his name cleared, as well as a number of other details such as, for example, his outrage at being arrested by mere gendarmes, his taking offence at being forced to travel in a third-class carriage, rubbing shoulders with the dregs of society, instead of a first-class carriage, in which he was supposed to travel according to military regulations and for which he was willing to pay, and his imprisonment alongside common criminals, point to another possible line of interpretation of this investigation, in addition to the ethnic one. ${ }^{45}$

Coriolan Buracu, the Orthodox priest in Mehádia and Cena's friend, had presented the arrest in terms of ethnic conflict, which was undoubtedly a determining factor in the arrest and subsequent investigation. This was part and parcel of the endemic suspicion that the Hungarian establishment harbored against members of non-Hungarian nationalities, especially against those who engaged in cultural activities and were thus automatically labeled Pan-Slavs, Daco-Romans, or Pan-Germans and as such guilty of Vaterlandsverrat. What comes across in the War Archive reports, however, is that for Cena himself the arrest was not so much an ethnically connoted act as it was a social affront and a demotion from his exalted civil and military status: As a major general, he knew very few superiors, and he was addressed in official correspondence as "Eure Excellenz." ${ }^{46}$ In his report to the General Staff of the 7th Army Corps in Temesvár, asking for a military assessment of the evidence brought against Cena, the royal chief prosecutor in Temesvár stressed the urgency with which a reply was expected "given Cena's exalted social status and the fact that he was under preliminary arrest." 47

As pointed out earlier in this article, Cena was not of noble or moneyed origin; he came from a Military Border peasant background and rose from the ranks on his own merits. His exalted military rank, however, inevitably translated into an enhanced social status. And this was true

\footnotetext{
${ }^{42}$ Moll, "Erster Weltkrieg und Ausnahmezustand, Zivilwaltung, und Armee: Eine Fallstudie zum innerstaatlichen Machtkampf im steirischen Kontext," 395.

${ }^{43}$ For a brief presentation of the Ehrenrat, or council of honor, see Alan Sked, The Survival of the Habsburg Empire: Radezky, the Imperial Army and the Class War 1848 (London/New York, 1979), 27.

${ }^{44}$ OeStA, KA, KM Präs, 1914, Karton 1565 (14/8-14/21/20/1), Aktenzahl 14-20/10:

"Ich habe dem Vaterlande und meinem Kaiser durch 41 Jahre treu, ehrlich, in vollen Ehren und verdienstvoll gedient und will mein Leben auch als Ehrenmann, nicht aber mit dem Schatten der Schande befleckt, beschließen."

${ }^{45}$ Nicolai Cena, Protokoll, 29.08.1914, KA, KÜA 1914, Aktenzahl 4066.

${ }^{46}$ As Deák points out, "Exzellenz" was the appellation due to two-star generals (FML) and above. István Deák, Beyond Nationalism: A Social and Political History of the Habsburg Officer Corps (New York/Oxford, 1990$), 16$.

${ }^{47}$ OeStA, KA, KM Präs, 1914, Karton 1583 (40/1-41/3), Aktenzahl 40-19/5, Confidential report A cs. és kir. 7. hadtest Vezérkari Osztályának, from Dr. Gozsdu Elek, Royal Chief Prosecutor with the Royal Tribunal in Temesvár, dated 22 August 1914, f. 12v: "Figyelemmel Csena Miklós magas társadalmi állására és arra, hogy előzetes letartóztatásban van: kérem a véleménynek sürgős közlését.”
} 
for several reasons. In the territory of the former Military Border, where for a long time the only hierarchy had been the military one, there being no local nobility, only peasant-soldiers and their commanders, military status was identical with social status. Within a broader social context, even if Cena's knighthood (he was a holder of the Ritterkreuz des Franz JosephOrdens) was not tantamount to being part of the nobility, it was nevertheless a distinction that marked his entry into the next best thing, that is, the service nobility. Finally and perhaps most importantly, he was a high-ranking member of the k.u.k. officer corps, an exclusive club that jealously guarded appearances and looked upon itself "as the first and most distinguished class" in society ("Wir, Soldaten, als der erste und vornehmste Stand," 48 as Crown Prince Rudolf put it in 1887). That was the logic behind the practice of Heiratskaution, the sum of money any officer had to lay down if he wished to marry, as proof that even if married he could still maintain the standard of living an officer had to preserve in order to honor his military status and not damage the prestige of the officer corps. It was this social self-consciousness and wariness that one's individual condition should not affect the good name of the profession that prompted Cena to make a point of changing his uniform for civilian clothes when he was arrested by mere gendarmes: A gendarme could not arrest an imperial general, who, even if suspected of the highest treason, was still supposed to be arrested by an officer and prosecuted by military authorities. In changing clothes, Cena drew a clear line between his civilian and military status to avoid tarnishing the emperor's uniform through this irregular arrest.

From the exchange of reports and notes within the War Ministry surrounding Cena's demand for satisfaction, it becomes apparent that, irrespective of whether Cena's own actions were deemed to have been correct or not, the referees were unanimous that satisfaction should be given by the War Ministry and also that Cena's arrest reflected badly on the officer corps as a whole and could not be made light of. Given the state of impending war, the head of the 4th Department (4. Abteilung) in the War Ministry showed some understanding for the increased security measures that had resulted in the arrest of Cena. He pointed out that Cena himself as a k.u.k. officer should have been more careful not to awaken suspicion. Irrespective of this, however, he also deemed it necessary for satisfaction to be given to Cena in view of his high military rank and the offense given to him. ${ }^{49}$

A more sympathetic view amounting to the same conclusion-that satisfaction was necessary-was that of Colonel Georg Domaschnian of the 5th Division in the War Ministry, who contributed his own personal testimony on Cena's upright character (Domaschnian was himself a native of the Banat Military Border) and urged that amends should be made to Cena in vindication to the officer class, whose image had been affected by Cena's ill treatment at the hands of the civilian authorities:

I feel in duty bound to inform you that I have known Major General Cena since I was a child, that I respect and consider him a model officer, who is held in high regard by everyone in his communityHungarian chauvinists excepted. If sufficient satisfaction is not granted to Major General Cena, this would give the impression that the officer in general-the first class in the Monarchy-has been

\footnotetext{
${ }^{48}$ Allmayer-Beck, "Die Bewaffnete Macht in Staat und Gesellschaft," in Die Habsburgermonarchie (1848-1918), Band V (Vienna, 1987), 1-141, at 107-8.

${ }^{49}$ OeStA, KA, KM Präs, 1914, Karton 1583 (40/1-41/3), Aktenzahl 40-19/5-2, Vorstand der 4. Abt. im k.u.k. Kriegsministerium, REFERAT zu Präs. Nr. 13966 von 1914 betreffend den FMLt. d.R. Nikolaus CENA, 19-20.
} 
abandoned to the whims of the civilian administration, which could have detrimental effects on the loyal population of the former Border. ${ }^{50}$

One assumes that Cena was indeed given some sort of satisfaction for the moral injuries sustained during this irregular arrest and detention, although the interdepartmental documents of the War Ministry do not actually provide any details on it.

\section{Conclusion}

The present article has been a contribution to the literature on internal repression in AustriaHungary during World War I and has examined the arrest of a retired k.u.k. general in southern Hungary during the partial mobilization decreed on 26 July 1914. As the documents show, it was not only the military, but also the civilian authorities that were in charge of the wave of arrests and investigations that accompanied the partial mobilization for war in the Hungarian half of the monarchy. In Hungary this was clearly legislated by the Emergency Law, which concentrated all exceptional powers into the hands of the Hungarian government and not the military. The Cena case shows the extent to which the Hungarian civilian authorities were involved in this initial spate of arrests. Even though the order of arrest came from the k.u.k. military authorities in Temesvár, the military were not involved in carrying it out, nor in drawing up the lists of suspects, which had already been in place before the order arrived. In the Cena case, the investigation was conducted by civilian authorities despite the fact that Cena was a member of the military (even if a retired one). The central military authorities in Vienna, moreover, relied on information from the Hungarian Ministry of the Interior, and this information turned out to be erroneous, although it is not clear from the extant documents whether this was because of a miscommunication or because of an intention to mislead. The eventual release of Cena came about on Prime Minister Tisza's initiative and authority.

What sets this particular case apart from others is the fact that Cena was a retired general in the imperial army and his status created the expectation of a certain treatment and of certain procedures to be followed, which should have distinguished him from ordinary suspects. Moreover, his military rank entitled him to an appeal to the authorities in Vienna, circumventing Hungarian institutions and also, by virtue of his military status, holding these Hungarian institutions responsible for any procedural irregularities. As the above-quoted Colonel Domaschnian pointed out in his defense of Cena, what was at stake in the hasty arrest of the general by Hungarian authorities in the summer of 1914 was, according to a corporatist, pars-pro-toto rationale, the prestige of the imperial officer corps as a whole. What was also being played out in this particular investigation was the tug-of-war between military and civilian jurisdiction in the Hungarian half of the monarchy.

\footnotetext{
${ }^{50}$ OeStA, KA, KM Präs, 1914, Karton 1583 (40/1-41/3), Aktenzahl 40-19/5-2, 5. Abteilung des k.u.k. Kriegsministeriums, Bemerkung, f. 18v: "Ich fühle mich verpflichtet zu melden, daß ich Seine Exzellenz den Feldmarschalleutnant CENA aus meiner Jugendzeit her kenne, achte und als Vorbild eines Offiziers schätze, der in seiner Heimat bei jedermann-magyarische Chauvinisten ausgenommen-in hohem Ansehen steht. Wird dem Feldmarschalleutnant CENA keine ausreichende Genugtuung zuteil, so wird dies den Eindruck machen, daß der Offizier in allgemeinen-der erste Stand im Reiche-der Willkür der Zivilverwaltung ausgesetzt ist, was bei der loyalen Bevölkerung in der ehemaligen Grenze die bösesten Folgen zeitigen könnte.”
} 
The image conveyed by the documents is not, however, that of a definite chain of command behind prewar arrests, but rather of military orders carried out by civilians on the basis of locally compiled lists of suspects. This confirms the evidence provided by Moll in his study of the Slovenes in Styria and points to a multiplicity of deciding factors and a rather disjointed process of command in which the military was not always aware of what the civilian authorities were doing. As the Austro-Hungarian ambassador in Bucharest warned, an egregious arrest such as Cena's would only antagonize public opinion in Romania, which by 1914 was still a friendly neighbor, headed by a Hohenzollern king and still bound by treaties to the Central Powers. The fact that Cena's arrest did take place, although Austria-Hungary was not at war with Romania and there would have been little reason to be suspicious of Romanians' loyalties at that stage in the war, further corroborates the idea that the chain(s) of command in the monarchy did not function flawlessly. Many arrests had nothing to do with the raisons d'état of higher level policymakers: They occurred thanks to local initiative and were only brought to the attention of higher civilian and military authorities when they rocked the boat too much.

Note on the Use of Place Names: For the sake of consistency, in the present article I have opted to use those place names that were in use at the time, that is, in 1914, unless an English-language equivalent is available: e.g., Temesvár, Karánsebes, Mehádia, Ujvidék, instead of the current versions Timişoara, Caransebeş, Mehadia, Novisad.

Abbreviations of Primary Sources:

OeStA = Österreichisches Staatsarchiv (Austrian State Archives, Vienna)

$\mathrm{KA}=$ Kriegsarchiv (War Archives, Vienna)

KM Präs = Kriegsministerium Präsidium (War Ministry Presidium)

KÜA $(\mathrm{MK} / \mathrm{KM})=$ Kriegsüberwachungsamt (War Surveillance Office)

ANCN = Arhivele Naționale Cluj-Napoca (Cluj-Napoca National Archives, Romania)

Military and historical abbreviations:

The highest rank for general officers in the Austro-Hungarian army was that of Feldmarschall (FM), a five-star general equivalent to a U.S. general of the Army and a British field marshal. In 1915, the rank of Generaloberst was introduced, which was the equivalent to a four-star rank of the U.S. and British general. This was followed by the Feldzeugmeister (FZM), which was on a par with General der Infanterie and General der Kavallerie (GdC) - all of them three-star general ranks equal to a lieutenant general in the U.S. and British armies. A Feldmarschalleutnant (FML) was a two-star general's rank, which was equal to the U.S. and British major general. The lowest rank for general officers in the k.u.k. army was that of Generalmajor (GM), a one-star general's rank equivalent to the British brigadier and the U.S. brigadier general.

k.k.-kaiserlich-königlich (imperial-royal) - after 1867 used in reference to institutions pertaining to Cisleithania.

k.u.k.-kaiserlich und königlich (imperial and royal)-after 1867 used in reference to the common institutions of the Austro-Hungarian Monarchy, with the exception of the army, which became k.u.k. after 1888 .

k.u.-königlich ungarisch (royal Hungarian) - used in reference to Hungarian institutions postAusgleich.

IrINA MARIN earned her PhD at the School of Slavonic and Eastern European Studies, University College London, in 2009. The title of her thesis is "The Formation and Allegiance of the Romanian Military Elite Originating from the Banat Military Border." 